\title{
The body fables in Babrius, Fab. 134 and 1 Corinthians 12: Hierarchic or democratic leadership in crisis management?
}

\begin{tabular}{|c|c|}
\hline \multicolumn{2}{|c|}{$\begin{array}{l}\text { Author: } \\
\text { Ruben Zimmermann }{ }^{1,2} \text { (D) }\end{array}$} \\
\hline \multicolumn{2}{|c|}{$\begin{array}{l}\text { Affiliations: } \\
{ }^{1} \text { Protestant Faculty, Johannes } \\
\text { Gutenberg University, Mainz, } \\
\text { Germany }\end{array}$} \\
\hline \multicolumn{2}{|c|}{$\begin{array}{l}{ }^{2} \text { Department of Old and New } \\
\text { Testament Studies, Faculty of } \\
\text { Theology, University of the } \\
\text { Free State, Bloemfontein, } \\
\text { South Africa }\end{array}$} \\
\hline \multicolumn{2}{|c|}{$\begin{array}{l}\text { Corresponding author: } \\
\text { Ruben Zimmermann, } \\
\text { ruben.zimmermann@ } \\
\text { uni-mainz.de }\end{array}$} \\
\hline \multicolumn{2}{|c|}{$\begin{array}{l}\text { Dates: } \\
\text { Received: } 03 \text { Feb. } 2021 \\
\text { Accepted: } 09 \text { June } 2021 \\
\text { Published: } 20 \text { Aug. } 2021\end{array}$} \\
\hline \multicolumn{2}{|c|}{$\begin{array}{l}\text { How to cite this article: } \\
\text { Zimmermann, R., 2021, 'The } \\
\text { body fables in Babrius, Fab. } \\
134 \text { and } 1 \text { Corinthians 12: } \\
\text { Hierarchic or democratic } \\
\text { leadership in crisis } \\
\text { management?', HTS } \\
\text { Teologiese Studies/ } \\
\text { Theological Studies } \\
77(4) \text {, a6524. https://doi. } \\
\text { org/10.4102/hts.v77i4.6524 }\end{array}$} \\
\hline \multicolumn{2}{|c|}{$\begin{array}{l}\text { Copyright: } \\
\text { (C) 2021. The Authors. } \\
\text { Licensee: AOSIS. This } \\
\text { is licensed under the } \\
\text { Creative Commons } \\
\text { Attribution License. }\end{array}$} \\
\hline \multicolumn{2}{|l|}{ Read online: } \\
\hline 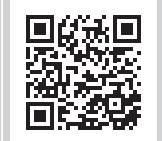 & $\begin{array}{l}\text { Scan this QR } \\
\text { code with your } \\
\text { smart phone or } \\
\text { mobile device } \\
\text { to read online. }\end{array}$ \\
\hline
\end{tabular}

Body metaphors and body fables were frequently used in ancient discourse for social communities and politics. This article will examine a body fable by the Greek fabulist Babrius (Babrius, Fab. 134) that has been overlooked in research so far. It shows a remarkable similarity to 1 Corinthians 12 through the use of central terms such as $\sigma \tilde{\omega} \mu \alpha$ and $\mu \dot{\varepsilon} \lambda \varsigma_{\varsigma}$ or personified speaking body parts such as an eye and head. Even if no literary direct dependence is claimed, the text, which was written at about the same time as 1 Corinthians, sheds light on Paul's understanding of the body fable. It becomes apparent, however, that the rhetorical function is fundamentally different in the two texts. Whilst the body fable in Babrius reinforces hierarchical structures, Paul emphasises the equality of the various body parts. The discussion about the 'implicit ethics' of these two texts is hermeneutically embedded in the current Corona crisis and the management of the crisis in different forms of organisation and state.

Contribution: The contribution makes the overlooked Babrius Fable 134, a body fable in political context, known in New Testament scholarship. A comparison with 1 Corinthians 12 points out that despite close analogies in plot and vocabulary, the message regarding the social structure diverges radically: While Babrius propagates a reinforcement of hierarchical leadership, 1 Corinthians 12 pleads for a community based on equivalence.

Keywords: body; Fable; Babrius; Paul; metaphor; hierarchy; equivalence; diversity.

\section{Introduction}

During the coronavirus disease (COVID-19) pandemic, there is a call for strong leadership in politics (and in the church). The hesitant and revisionist approach of several democratic governments in the Western world sometimes led to high death tolls, social and economic disasters. This provoked resistance in the population. There are movements in several Western countries that doubt the competence of the government and see a lack of foresight and transparency in its decisions. The situation is quite different in China: although the country of origin of the pandemic, China has emerged from the crisis with comparatively few deaths and economic growth. The government of the People's Republic of China attributes this success last but not least to its strong leadership ${ }^{1}$, which - seen from the outside - is hierarchically and undemocratically structured and entails great restrictions on the freedom of the individual. Even if this dualistic representation is highly simplified, a clear tension is evident from it that can be formulated best as a simple question: Is a hierarchical form of government superior to a democratic one in times of crisis? In the face of special challenges such as the COVID-19 pandemic or possibly also climate change, do the actually existing democracies of Western societies reach their limits because they are only capable of acting with difficulty, cannot find a uniform approach in federal forms of government (e.g. in Germany) and do not have power structures that can make the necessary decisions in a short time?

Already in antiquity, the metaphor of the body was used to reflect on political conditions. The best known is the frequently documented body fable with which the patrician Menenius Agrippa was able to put an end to an uprising of the plebeians. The New Testament research has largely agreed that Paul was influenced in a direct or indirect way by these or similar fables when he formulated his remarks to the church in Corinth in the image of a body according to 1 Corinthians 12.

1.Under the strong leadership of the CPC Central Committee with $\mathrm{Xi}_{\mathrm{H}}$ Jinping at its core, China has put in place an efficient system under which the central authorities exercise overall command, while local authorities and all sectors follow the leadership and instructions of the central authorities, perform their respective duties, and cooperate with each other." See Fighting Covid-19. China in Action, ed. by the State Council Information Office of the People's Republic of China, http://www.scio.gov.cn/zfbps/32832/Document/1681809/1681809.htm

Note: Special Collection: From timely exegesis to contemporary ecclesiology: Relevant hermeneutics and provocative embodiment of faith in a Corona-defined world - Festschrift for Stephan Joubert, sub-edited by Willem Oliver (University of South Africa). 
However, it can be demonstrated that the application of the body metaphor to a social unit can be quite different. In the case of Babrius 134 and 1 Corinthians 12, the same fable material is used at cross purposes, once to stabilise hierarchical power structures and once to undermine them.

\section{Babrius, Fab. 134 and other body fables in antiquity}

The metaphor of the body and its limbs applied to social groups is found in many contexts in ancient discourse (Brookins 2016:77-88; Lee 2006:29-45). Within this broad group of social body-metaphors, the fable of Menenius Agrippa now stands out, which not only shows a narrative design itself, but is also firmly integrated into the story of a plebeian revolt in different variants of tradition. The most comprehensive listing of this fable in the various sources can be found in Nøjgaard (1967:425; cf. Van Dijk 1997:312). Nøjgaard even suggested an Egyptian origin of the fable material, which is then differentiated into two branches of the Greco-Latin tradition, one establishing an opposition between head and limbs (e.g. Maximus Tyrius Dissertationes XV 5) and one between belly and limbs (Nøjgaard 1967:426; similarly Adrados 2000:106-107). The latter is found far more frequently. For example, there is a short Latin version in Quintilian (Inst. V 11.19) and a longer Latin version in Livy (Hist. II 32.7-33.1). In addition, Greek versions are known in the Augustana collection of Aesop's fables Aes. 130 (Perry 1952:371-372), in Plutarch's biography of Caius Marcus Coriolanus (Cor. 6.1-4) and Dionysius of Halicarnassus in his Roman Antiquities (Ant. Rom. VI 86.1-5). Despite the not inconsiderable differences and variations in the details (see Smith 2018:147-150), many versions converge in that individual body parts such as the hand and foot join forces and rebel together against the belly, which is accused of inactivity. When they stop working, however, their own strength also dwindles and they are in danger of starving to death. So they must painfully admit that only the interaction of the different parts of the body, including the belly, ensures the life of the body. The function of the fables is also largely identical as they are mostly about persuasion in politicalsocial discourse (Zafiropoulos 2001:98-107 'political fables') to consolidate hierarchical structures. In the narrative context, the Roman consul Menenius Agrippa (ca. 5th century BC) succeeds in appeasing the rebellious people and persuading them to recognise the leading role of the Senate (cf. Nestle 1948:350-360). The sources also agree that the text is a fable. Quintilian explicitly speaks of 'fabella' (Inst. V 11,19) and Dionysus of Halicarnassus explicitly assigns the fable to the Aesopic tradition (see Ant. Rom. VI 83.2: 'a fable [ $\mu \tilde{0} \theta$ os] composed after the manner of Aesop'; Plutarch also speaks of $\mu \tilde{\theta} \theta 0 \varsigma$, Corinthians 6.2, cf. on terminology Adrados 2002:172).

The source situation gives the impression that the body fable is one of those fables that were frequently handed down amongst historians and rhetors but did not find their way into the early fable collections. Indeed, in the surviving version of Phaedrus's fables, we do not find it. In the Greek collection of fables by Babrius, however, there is a fable that takes up the material of the body fable but adapts it in its own way and makes it more pointed (Babrius, Fab. 134). According to Adrados, the material of Babrius, Fab. 134 comes from the same Egyptian source as the other body fables. At the same time he acknowledges (Adrados 2000):

Babrius, who offers a long fable of 19 verses with a very varied theme (now it is the serpent's head and tail) (...), creates a very original fable, with long narrations and dialogues. (p. 199)

Similarly, Holzberg emphasised the originality of Babrius, who 'created a dramatic and, moreover, highly amusing scene out of the sparse narrative of tradition (e.g. seven lines in Plutarch)' (Holzberg 2019:36).

The two-volume Greek-language fable collection of Babrius, also called 'Mythiambs' (cholic Iambs) after the verse meter, is largely unknown. Even classical philologists lament that Babrius may well be amongst the most neglected poets of distinction in his own discipline (Holzberg 2019:9). The experts date Barbius to the first or

BOX 1: Babrius 134 (Text and Translation).

\begin{tabular}{|c|c|c|}
\hline Verses & $\begin{array}{l}\text { Babrius Fable } 134 \text { (eds. Luzzatto \& } \\
\text { La Penna 1986:130-131 = ed. } \\
\text { Holzberg 2019:1821) }\end{array}$ & $\begin{array}{l}\text { Translated according to Perry } \\
\text { 1965:175 }\end{array}$ \\
\hline 1 & 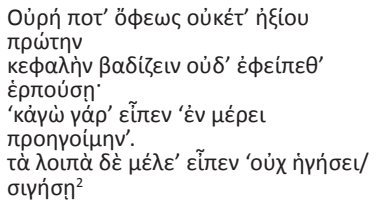 & $\begin{array}{l}\text { Once a snake's tail decided that } \\
\text { the head ought no longer to go } \\
\text { first and refused to follow its lead } \\
\text { in creeping along. } \\
\text { 'Let it be my turn now', it said, 'to } \\
\text { lead the way'. } \\
\text { 'Don't lead/Keep still', said the } \\
\text { other members, }\end{array}$ \\
\hline 5 & 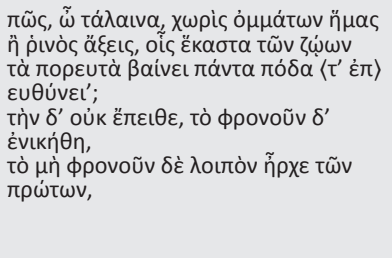 & $\begin{array}{l}\text { 'how can you lead us, poor wretch, } \\
\text { without any eyes or nose, the means } \\
\text { by which all living creatures move on } \\
\text { their way and guide each limb?' } \\
\text { But they could not dissuade the } \\
\text { tail from its purpose, and the } \\
\text { rational part of the body } \\
\text { succumbed to the irrational. } \\
\text { Thereafter the hinder parts ruled } \\
\text { the foremost. }\end{array}$ \\
\hline 10 & 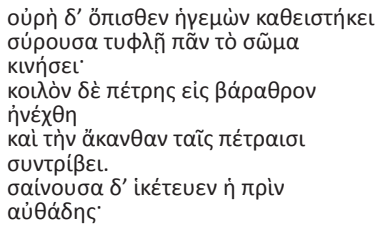 & $\begin{array}{l}\text { The tail became the leader, } \\
\text { dragging the whole body along in } \\
\text { blind motion. } \\
\text { It fell into a hollow pit and bruised } \\
\text { the spine on the sharp rocks. } \\
\text { Then the tail, which had been so } \\
\text { self-willed before, became } \\
\text { submissive and turned to } \\
\text { supplication saying: }\end{array}$ \\
\hline 15 & 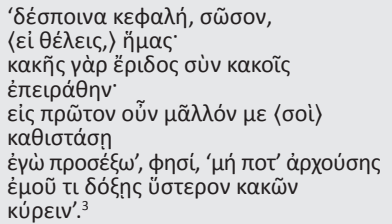 & $\begin{array}{l}\text { 'Mistress head, save us, if you will. } \\
\text { 'Twas an evil strife that I ventured } \\
\text { on, and evil has been the } \\
\text { consequence. } \\
\text { If you'll put me where I was at first } \\
\text { I'll be more obedient and you'll not } \\
\text { worry about getting into trouble } \\
\text { again under my leadership'. }\end{array}$ \\
\hline
\end{tabular}

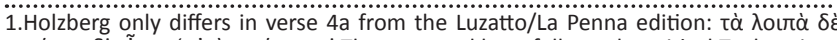

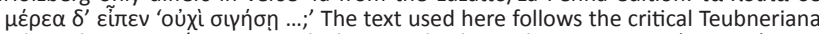
edition by Luzatto/La Penna, which is mostly identical to Perry 1965 (LCL 436), 174, including the reconstruction on v. $4 \mathrm{~b}$ by Perry and Holzberg (see fn. 2). The codex Oxon. Bodleianus and Codex Vaticanus Graecus Palaatinus Graecus $367(\mathrm{Ba} \mathrm{Bb})$ read

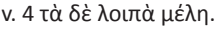

2.The last section of verse 4 is difficult to read. Whereas Luzatto/La Penna

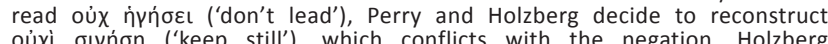
translates this as a rhetorical question: 'Willst du nicht still sein?' (Holzberg 2019:183)

3.Verses 16-19 are omitted in Ba Bb, followed by Rutherford 1883:126. Codex Athous, however, witnesses these verses, which follow the more recent editions. 
early second century CE, furthermore linguistic parallels to the LXX and the New Testament are found (Luzzatto 1975:52-63) and in the second prologue the Syrian origin of the fables is even explicitly named (for details on Babrius, see Holzberg 2002:52-61; Strong 2019:135-156; Zimmermann 2021). These historical contexts alone make Babrius 134 an interesting intertext for 1 Corinthians 12, which has not been studied in its own right (briefly mentioned in Strong 2019:574 fn. 1129).

In the following, I would like to present the largely unknown text of Babrius, Fab. 134, analyse it with narrative methods and interpret it with regard to the initial question of a functional application.

\section{Narrative Reading of Babrius, Fab. 134}

The term oủn (tail), strikingly placed twice at the beginning of the verse, reveals a two-part structure, with Part 1 (verses 1-9) dealing with the verbal revolt of the tail with subsequent debate. Part 2 (verses 10-19) describes the realisation together with the disastrous consequences.

Part 1 can be divided into three sections: Verses 1-2 provide an introduction to the problem: the tail no longer wants to

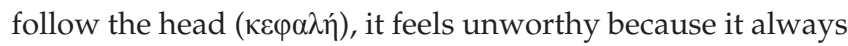
has to crawl behind and is not allowed to go 'first' itself.

The second subsection begins with verse 3 , which is a dialogue: The description of the problem is brought to a head with a verbal speech of the tail: he also wants to lead

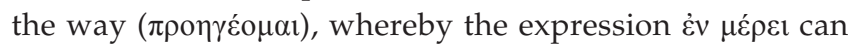
mean 'part by part' or 'one after another', or simply indicates that it is his turn to lead. Although in the introduction the head was addressed as the explicit opponent of the tail, surprisingly it is not the head that now

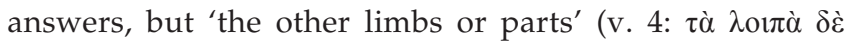
$\mu \varepsilon \dot{\lambda} \varepsilon \alpha / \mu \varepsilon \dot{\varepsilon} \rho \varepsilon \alpha)$ : they are indignant about the proposal (emphatically with $\tilde{\omega} \tau \alpha \dot{\lambda} \lambda \alpha v \alpha$ ) and refer by means of a rhetorical question to elementary deficits of the tail for this task. How can you lead if you have no eyes and no nose as the necessary body parts for navigation? This objection is backed up by an argument by way of a generalisation: all

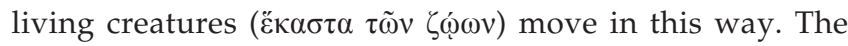
head directs the feet. The feet break the image of the snake. It may still be attributed to the limited knowledge of zoology that the nose is specifically named as an organ of orientation. For snakes do have a nose, but it is through this nose that they primarily breathe. The smell organ, the so-called vomeronasal sense, however, is located in the tongue of the snake. However, the picture is abandoned when it comes to the feet, because snakes do not have feet. Babrius knew very well how to distinguish between lizards and snakes, as Babrius, Fab. 41 proves. One might therefore consider whether the explicit mention of feet does not

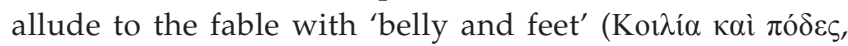
Nr. 130 according to Adrados 2002:170; Perry 1952:371), which is not infrequently mentioned in the group of body fables (Peil 1985:17), in which the interplay between belly and feet is transferred to the leadership function of army command over the soldiers. This assumption is supported by the fact that the epimythion of the foot-belly fable explicitly mentions the 'rational' with which the army leaders are to guide the untrustworthy (oi $\sigma \tau \rho \alpha \tau \eta \gamma o$ ò $\alpha i \sigma \tau \alpha$

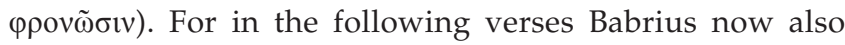
speaks of the 'rational' alongside the 'irrational'.

In the authorial narrative style, verses 8-9 sum up the result of the dialogue in a third section. Despite the obvious majority of the other limbs, they cannot dissuade the tail from its goal. The first part concludes with a comment by the narrator, which is stylistically out of the ordinary in the sense that there is now no longer talk of body parts in a descriptive manner, but the head functionally abstracted by 'thinking' ( ò $\varphi \rho$ ovoṽv): In strict parallelism we are told:

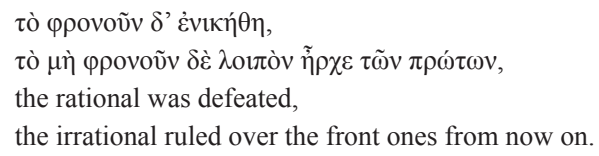

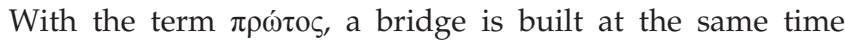
between the last word in verse 9 and the last word in verse 1 , so that the first part is rounded off with a great inclusio.

The second part of the fable (v. 10-19) now tells of the practical realisation of this change of rulership, whereby two sections can be distinguished. Verses 10-13 tell of the reversal of leadership and the catastrophe. As is often the pattern in Babrius, the fable concludes with a literal speech, which - as here - functionally replaces the epimythion and has as its subject the repentance of the tail.

As mentioned here, the second part also begins with the preceding mention of the tail (ovjpr, v. 10, but this time without reference to the serpent) and reports that it was indeed used as a guide (i $\gamma \varepsilon \mu \omega \dot{v})$. He dragged the whole

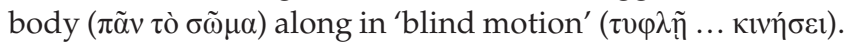
The blindness of the leading tail now allows the reader to see what the rest of the body had already foreshadowed. 'Without eyes' (v. 5), the way can only end in the abyss. Indeed, the serpent plunges down a deep precipice and smashes its backbone against the rocks (v. 12-13).

The proverbial motif of a 'blind guide' is widespread in antiquity. Even Plato speaks critically of 'blind choir leaders' who fail as political leaders or teachers (Plato, resp. 8, 554B, cf. Philo virt. 7). Babrius, Fab. 134 thus first uses a common metaphor to ironically illustrate the inability of a leader. The motif could also be sharpened to the effect that a 'blind man cannot lead the blind'. Such a formulation is known from a rhetorical question parable that is also found in the early Christian tradition: 'How can a blind man lead a blind man? Will they not both fall into a pit?' (Lk 6:39/Mt 15:14; GThom 34, see Kern 2015:61-67). The terms from the semantic fields 'lead', 'blindness' and the 'fall' (into a pit or abyss) show a motivic proximity between Babrius, Fab. 134 and the early Christian parable, although different Greek terms are used in detail. 
De facto, however, the blind tail in Babrius' scenario does not lead 'blind limbs' but, amongst other things, also the head with its eyes. The catastrophe in Babrius thus arises particularly because the blind tail wants to guide the seeing head. After the painful fall, the snake's tail also realises how unreasonable this attempt was.

With a long final speech spanning five verses (v. 15-19), the previously insolent braggart now shows his repentance. The speech consists of these parts: plea, confession of guilt and promise. Firstly, the tail submissively begs the head directly ( $\delta \varepsilon \dot{\sigma \pi o t v \alpha ~ \kappa \varepsilon \varphi \alpha \lambda \eta ்) ~ f o r ~ s a l v a t i o n ~(v . ~} 15 \sigma \tilde{\omega} \sigma o v)$, obviously aware that any claim to it is squandered (v. 15a: 'if you will'). Then there is a full admission of wrongdoing. The desire for corule, initially presented as legitimate in the sense of equality of body parts, is now interpreted as an evil 'quarrel' ('̌pı) leading to evil consequences. The tail even calls his behaviour a 'temptation' (v. 16: $\pi \varepsilon 1 \rho \alpha ́ o \mu \alpha)$ ). It might be going too far to think of 'temptation' here in the sense of a radical questioning of legitimate power. Nevertheless, it is worth noting in the intertextual dialogue that the term $\pi \varepsilon i \rho \alpha \sigma \mu$ ó $\varsigma$ in the biblical tradition describes both man's misconduct against God (see Ex 17:7; Dt 9:22; Mt 6:13) and Jesus' 'temptation' by Diabolos (Lk 4:13). The semantic spectrum of the chosen Greek verb includes at least this dimension of rebellious behaviour against a higher authority (even in the religious sense).

Finally, the tail takes a kind of new oath of allegiance, as is

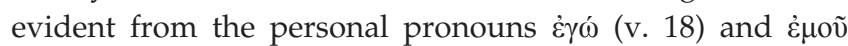
(v. 19) positioned twice at the beginning of the verse. Not only does he promise to return to his former position, but he wants to be devoted in the future ( $\pi \rho \circ \sigma \varepsilon \xi \xi \omega$ future tense!) and forever $\left(\mu \eta \dot{n} \pi \tau^{\prime}\right)$ to the supremacy of the head.

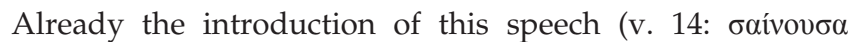
flattering), as well as the exaggerated self-condemnation of

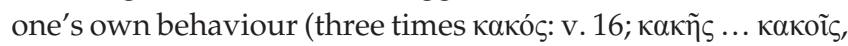
v. 19: $\kappa \alpha \kappa \tilde{v})$ or the salutation used not only for the mistress of the house but also still for goddesses: $\delta \varepsilon \dot{\sigma} \pi$ orva (v. 15) do not allow us to overlook a certain irony in the representation. Whilst at the beginning the tail refuses to crawl behind, at the end it metaphorically 'crawls' to make amends with the head. The one who at the beginning (v. 1) criticises the lack of dignity of his inferior status must at the end degrade himself in an unprecedented way. If one reads the text from the position of the powerful, one can undoubtedly be amused by the ironic and exaggerated presentation of the scene (with Holzberg 2019:36). The message, however, that is at least implicitly conveyed, also ends up very seriously: the supremacy of the head was ultimately confirmed by the little revolt. By the tail having to acknowledge its subordination in such a radically disarming way, the distance between the leading power (here the head) and the subordinated parts of the body (here the tail) is thus reaffirmed in the end.

The terms from the semantic field of ruling, such as $\delta \varepsilon \delta \sigma \pi o v \alpha$

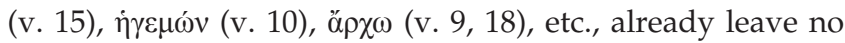
doubt on the figurative level that we are dealing here with a fable that explores a political dimension and can therefore also easily be assigned to the other political body fables. However, one can also clearly see the significant differences between the Babrius fable and the other versions.

For one thing, a contrast is established between head and body (otherwise only Maximus Tyrius XV 5) and not, as in Livius, Plutarch etc., between body parts and belly. Furthermore, the majority ratios differ. Whilst in the bodybelly fables the many body parts rebel against the one belly, in Babrius the tail seems to stand in lonely opposition not only against the head but also against the other parts of the body. They protest against the revolutionary thoughts of the tail right at the beginning. In the literal speech (v. 4-7), the primacy of the head (specifically then the eyes and the nose as pars pro toto) over the feet is acknowledged without dispute.

Furthermore, in the narrative embedding of Menenius Agrippa, the fable serves to bring the plebeian revolt to a peaceful end. The senator Agrippa is thus in the role of supplicant, trying to convince the plebs to abandon their revolution. Although structurally superior, the senator must nevertheless go to meet the insurgents and thus acknowledge their current position of power.

Already in Plutarch (Cor. 6:3) a certain reversal of these power relations is evident, for here the belly already laughs at the body parts in a gesture of contempt. In Babrius, the concern of the tail is presented as doomed to failure from the very beginning. Most of the body parts do not support the insurgent. Through his blindness, he makes a fool of himself in the leading role. In the narrator's commentary (v. 8-9), guiding principles of philosophy and virtue ethics are used to describe the tail's endeavor as 'irrational' even before the action begins. Finally, the catastrophe that is often only hinted at in other fables is vividly painted in Babrius (the fall into the pit). The tail must finally humble and 'debase' itself (cf. v. 1).

Even if Babrius may have taken the choice of the animal (snake) and the tail (as a body part) from tradition (Van Dijk 1997:106-108; however, not from Aes. 130, see Perry 1952:371372), he undoubtedly also deliberately included the despised animal (see his degradation of the snake also in Babrius, Fab. $118,143)$ and the most despised body part (the tail, which produces excrements).

For Zafiropoulos (2001), the basic message of the body fables in general is that unequal parts in a political context can only work together through hierarchy and obedience:

When the parties are unequal, the only peaceful solution is that the relationship remains unbalanced and a hierarchy of power and obedience is accepted. The weak must obey the strong; the subjects must obey the leader; they must also trust him and never question the fairness of his actions. (p. 101)

This statement is particularly true for Babrius, Fab. 134. Compared with the other political body fables, Babrius, Fab. 
134 can be described as the fable that most clearly affirms the hierarchy and existing power structures and wants to nip any attempt at criticism and change in the bud. Babrius deformed the planned revolution into a cartoon in such a way that it presumably serves to amuse (the powerful) and no longer reflects a serious (political) issue.

This attitude connects with the view, which is also widespread in Babrius research, that the collection of fables was probably written in an upper class or even courtly milieu (Perry 1965:xlix; Van Dijk 2006:119-120). It is difficult to identify a specific socio-historical setting of the Babrius's fable collection. This setting can only be reconstructed from the text itself, which is highly rhetorical and even parodic. Even if the narrative location at the court of King Alexander (Babrius, Prologue II) hardly ascribes historical referentiality, it reflects the fundamental orientation towards the son of a powerful man. This consideration is also underlined by the statistical frequency of the animals, as the lion (the king of beasts and symbolic animal of the powerful) is the most frequently animal displayed as protagonist in the Babrius fables (18 times). Finally, the attitude of stabilising power can be observed in many other fables that exhort the maintenance of the existing order and dramatically demonstrate the failure of attempts to deviate from it (see Babrius, Fab. 21, 28, 41, 115, 129 etc.).

\section{The Body of Christ in 1 Corinthians 12:12-30}

In dealing with divisions and conflicts of evaluation in the church of Corinth, Paul also makes use of the metaphor of the body and the members in chapter 12. If one wants to hold to a strict genre distinction between fable and parable (Zimmermann 2015:143-145), then one could possibly recognise in 1 Corinthians 12:12-30 the only fable of the New Testament (Zimmermann 2014:650). Whilst the parable, despite its fictionality, creates a realistic scenario, many fables break through the possible world. Accordingly, Paul's speaking body limbs here also exceed the horizon of human experience.

Not only the closeness to the genre, but especially the terms that occur in 1 Corinthians 12 and Babrius, Fab. 134 make a comparison rewarding. In 1 Corinthians 12 , for example, the term body $(\sigma \tilde{\omega} \mu \alpha)$ dominates and is used no less than 18 times in verses 12-30. It also occurs in Babrius, Fab. 134.11. The

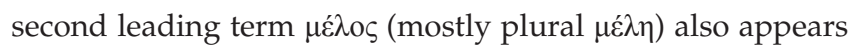
in 1 Corinthians 12 with conspicuous frequency (13 times) and again in Babrius, Fab. 134.4. The leading terms already indicate that 1 Corinthians 12 is precisely about the relationship between individual limbs or body parts amongst themselves or to the whole body. Moreover, 1 Corinthians 12 mentions the 'eye' (v. 16-17, 21), 'sense of smell' (v. 17), 'foot' (v. 14, 21) and 'head' (v. 21), amongst other parts of the body that also occur in Babrius, Fab. 134. Although there is no mention of the 'tail', parts of the body considered weak are also mentioned in Paul (1 Cor 12:22, 25).
In 1 Corinthians 12, it can hardly be denied that the parts of the body stand in a hierarchical relationship. From the rhetorical arrangement one can conclude that the hand is superior to the foot or the eye to the ear or the hand and again the head to the feet. Firstly, the 'inferior' body parts 'foot' and 'ear' speak up, asking whether they are needed for the body at all (1 Cor 12:15-16). Then the 'superior' organs, the 'eye' and the 'head', speak up with fictitious statements that could explain their independence ('I do not need you ...'; 1 Cor 12:21). Paul, however, through the rhetorical presentation (with negations) does not leave the slightest doubt that such speech of detachment would be meaningful. Rather, he skillfully formulates rhetorically with negations (v. 21: "The eye cannot say to the hand, "I have no need of you"') so that the addressees can only agree: Of course not! The individual limbs belong inseparably to the body; at the same time they remain mutually related to each other. Paul does not negate the diversity of the body parts, but criticises their different valence in common discourse. However, the apostle describes not only the interrelation of individual body parts but also emphasises the affiliation to the body as a whole: 'If the whole body were an eye, where would the hearing be? If the whole body were hearing, where would the sense of smell be?' (1 Cor 12:17).

To make the body function, the body parts must come together and work together precisely in their diversity. Thus, all the members are bound together and depend upon one another. Both, mutual dependence and diversity are required to make the body function. 'The body image implies that there is, and needs to be, diversity and difference amongst those that constitute the body' (Horrell 2013:362). Thus, the members are not equal, but of equal value, this is what Paul highlights. Verse 20 sums up: ṽ̃v $\delta \dot{\varepsilon}$ $\pi \mathrm{o} \lambda \lambda \dot{\alpha} \mu \grave{\varepsilon} \nu \mu \varepsilon \dot{\varepsilon} \lambda \eta, \tilde{\varepsilon} v \delta \grave{\varepsilon} \sigma \tilde{\omega} \mu \alpha$ ('there are many members, yet one body').

Paul, however, is not satisfied only with the purposeoriented functional unit. He explicitly also emphasises care and empathy. When one part suffers, the whole body suffers (1 Cor 12:26); equally, joy is shared. This 'sympathy' in a literal sense, for example, compassion, culminates in explicit care for the parts of the body considered weak or dishonourable. Paul argues from the experience of special care, for example, with clothes for these body parts: 'and those members of the body that we think less honourable we clothe with greater honour, and our less respectable members are treated with greater respect' (v. 23). The inferior member receives the greater honour (v. 24). Such togetherness exceeds the usual standards of a human social community. How can this work?

The answer is given theologically in 1 Corinthians 12: God, the creator, has arranged the body in this manner (v. 24). At the same time, it is not a human being or a human community (such as the polis, the state, etc.) that is identified with the body, but Christ: 'Now you are the body of Christ and individually members of it' (1 Cor 12:27). Belonging to the 
body of Christ gives all members, whether head or foot, the same closeness (and distance) to the body. Through this theological anchoring of the body, it is removed from human control.

The difference between the body fables in Paul and Babrius could hardly be greater. Whereas in Babrius, Fab. 134 the hierarchies are consolidated, Paul in 1 Corinthians 12 strives for equivalence. Whereas Babrius painfully forces the body parts to work together in order to (re)establish the body's ability to function, Paul propagates a harmonious interaction that even includes empathy and compassion between the parts. In this respect, Babrius, Fab. 134 is power-stabilising, whilst 1 Corinthians 12 is power-critical (cf. Martin 1995; Smith 2018:155-156), insofar as individual body parts are not allowed to claim higher value and honour. Rather, the inferior parts are given even greater honour.

\section{Conclusions and hermeneutical ethical reflection}

Even if the relevance of ancient texts in contemporary ethical discourses can only be considered with differentiated hermeneutical reflection (see Zimmermann \& Joubert 2017), it is nevertheless permissible to ask for some preliminary ethical insights in this article as well. This leads back to the initial questions. Are hierarchical structures superior to avoid catastrophes in the face of crisis experiences such as the Corona pandemic or the climate crisis? The answer of Babrius would be a decisive 'yes'. Admittedly, the fable Babrius, Fab. 134 does not yet begin with the crisis, but merely with the display of the problem in well-ordered situations. However, it broadly unfolds a catastrophe in its middle, which was ultimately caused by the reversal of power structure. It is easy to conclude that in presupposed crises, it is all the less permissible to move away from proven, hierarchical power relations in order not to intensify the crisis. Within Western democratic societies, however, one will hardly be willing to follow this implicit ethic of Babrius. Freedom of the individual is a good that cannot be sacrificed even and especially in a crisis.

The picture is quite different when we look at the current situation with 1 Corinthians. Paul is writing the letter in the midst of a crisis. There are already divisions in the congregation in Corinth (1 Cor 1:11; 11:18), which undoubtedly bring uncertainty and insecurity. Nevertheless, Paul does not advise stabilisation through hierarchical power. On the contrary, to cope with or overcome the dissension within the body, the members should have the same care for one another (1 Cor 12:25). It is this 'other regard' (Horrell 2005:274), the care for the weakest that ultimately constitutes the Christ's body. The immense care for the elderly and sick in the Corona crisis may be deeply rooted in the cultural memory of Western societies in the caring ideal of Early Christianity. Paul could hardly have imagined that the unity in diversity he described could function without being anchored and focussed on Christ. Diversity thus finds its limit in the orientation towards Christ and cannot become an objective in itself. In the body of Christ, even the vulnerable and marginalised can be included, but the ideal of diversity ends with extreme positions (e.g. conspiracy theorists) that ultimately harm the whole community. Thus, 'the body image implies that the members of one body share some common good' (Horrell 2013:362), for instance, mutual love and faith. Can Paul then still be a dialogue partner for politics and society today in an increasingly secularised world?

Does this then mean that both models of community as outlined in the body fables are unsuitable for the present situation? Is Paul distant from the world in his Christcentredness and Babrius cruel with his solidification of authority? Do the courtly Babrius and Paul as a street worker in the social underclass clash with irreconcilable opposites who use the body fable according to their basic convictions in a way that stabilises or is critical of power?

One could argue that both Babrius and Paul represent extreme positions that already have their value as a stimulus for discussion in the current debate. Babrius envisions-to his credit-a governance with reason, as he emphasises in the centre of the fable. Misanthropic, blind exercise of power by elites could not be justified even with Babrius, Fab. 134. Paul, for his part, speaks of unity in diversity and equality of members (in other words, basic principles of democracy, cf. Lindemann 1995:163-165), but in no way calls for a radical critique of power or legislates what diversity should look like. The way of speaking matters, for Babrius and Paul and for people today. The narrative ethics of fables do not provide simple instructions for politicians and other decision-makers. It serves as a discussion starter about values and norms. Furthermore, in the midst of a crisis, Paul creates a vision, a powerful image of a new community in solidarity and difference (Horrell 2013:356-363). If one is inspired by Paul, he or she will not search for more hierarchical policymaking in the current or future crises, but rather develop more visions that make it possible to look beyond the horizon of the crisis with hope.

\section{Acknowledgements Competing interests}

The author declares that they have no financial or personal relationships that may have inappropriately influenced them in writing this article.

\section{Author's contributions}

R.Z. is the sole author of this article.

\section{Ethical considerations}

This article followed all ethical standards for research without direct contact with human or animal subjects. 


\section{Funding information}

This research received no specific grant from any funding agency in the public, commercial or not-for-profit sectors.

\section{Data availability}

Data sharing is not applicable to this article as no new data were created or analysed in this study.

\section{Disclaimer}

The views and opinions expressed in this article are those of the author and do not necessarily reflect the official policy or position of any affiliated agency of the author.

\section{References}

Adrados, F.R., 2000, History of the Graeco-Latin Fable. Vol. II: The Fable during the Roman Empire and the Middle Ages, Brill, Leiden.

Adrados, F.R., 2002, History of the Graeco-Latin Fable. III: Inventory and Documentation of the Graeco-Latin Fable, Supplemented with new references and fables by GertJan Van Dijk, Brill, Leiden.

Brookins, T.A., 2016, 'Paul and the ancient body metaphor: Reassessing parallels', Journal for the Study of Paul and His Letters 6, 75-98.

Holzberg, N., 2002, The ancient Fable. An introduction, transl. C. Jackson-Holzberg, Indiana University Press, Bloomington, IN

Holzberg, N., 2019, Babrios Fabeln. Griechisch-Deutsch, Sammlung Tusculum, de Gruyter, Berlin.

Horrell, D.G., 2005, Solidarity and difference. A contemporary reading of Paul's ethics, T\&T Clark, London.

Horrell, D.G., 2013, 'Sōma as a basis for ethics in Paul', in F.W. Horn, U. Volp, R. Zimmermann \& E. Verwold (eds.), Ethische Normen des frühen Christentums. Gut. Leben. Leib. Tugend, pp. 351-363, WUNT 313, Mohr Siebeck, Tübingen.

Kern, G., 2015, 'Absturzgefahr (Vom Blinden als Blindenführer). Q 6,39 (Mt 15,14/Lk 6,39/EvThom 34)', in R. Zimmermann et al. (eds.), Kompendium der Gleichnisse Jesu, 2nd edn., pp. 61-67, Gütersloher Verlag, Gütersloh.

Lee, M.V., 2006, Paul, the stoics, and the body of Christ, SNTSMS 137, Cambridge University Press, Cambridge.

Lindemann, A., 1995, 'Die Kirche als Leib. Beobachtungen zur "demokratischen" Ekklesiologie bei Paulus', ZThK 92, 140-165.
Luzzatto, M.J., 1975, 'La Cultura Letteraria di Babrio', in Annali della Scuola Normale Superiore di Pisa. Classe di Lettere e Filosofia, pp. 17-97, Serie III, Vol. 5, No. 1 , Scuola Normale Superiore.

Luzzatto, M.J. \& La Penna, A. (eds.), 1986, Babrii Mythiambi Aesopi, Teubner Verlagsgesellschaft, Leipzig.

Martin, D.B., 1995, The Corinthian body, Yale University Press, New Haven, CT.

Nestle, W., 1948, 'Die Fabel des Menenius Agrippa', in W. Nestle (ed.), Griechische Studien. Untersuchungen zur Religion, Dichtung und Philosophie der Griechen, pp. 502-516, F. C. Hannsmann (first 1927 in Klio), Stuttgart.

Nøjgaard, M., 1967, La Fable Antique. Tome Deux: Les Grands Fabulistes, Nyt Nordisk Forlag, Kopenhagen.

Peil, D., 1985, Der Streit der Glieder mit dem Magen: Studien zur Überlieferungs- und Deutungsgeschichte der Fabel des Menenius Agrippa von der Antike bis ins 20. Jh, Lang, Frankfurt am Main.

Perry, B.E., 1952, Aesopica. A series of texts relating to Aesop or ascribed to him or closely connected with the literary tradition that bears his name. Collected and critically Edited, in Part Translated from Oriental Languages, with a Commentary and Historical Essay, Cambridge, New York, NY.

Perry, B.E., 1965, Babrius and Phaedrus Fables, eds. transl. B.E. Perry, Loeb Classical Library 436, Harvard University Press, Cambridge, MA.

Rutherford, W.G. (ed.), 1883, Babrius. With introductory dissertations, critical notes, commentary, and lexicon, Scriptores Fabularum Graeci 1, Macmillan and Co, London.

Smith, D.L., 2018, 'Why Paul's Fabulous body is missing the Belly: The rhetorical subversion of Menenius Agrippa's Fable in I Corinthians 12.12-30', Journal for the Subversion of Menenius Agrippa's Fable in
Study of the New Testament 41, 143-160.

Strong, J.D., 2019, 'The Fables of Jesus in the Gospel of Luke: Their form, origins, and implications', Dissertation Notre Dame, Revised version forthcoming as The Fables of Jesus in the Gospel of Luke: A New Paradigm for the Study of Parables, Brill, Leiden, 2021.

Van Dijk, G.-J., 1997, Ainoi, Logoi, Mythoi: Fables in Archaic, classical, and Hellenistic Greek Literature: With a study of the theory and terminology of the genre, Brill, Leiden.

Van Dijk, G.-J., 2006, 'Babrius. Writer of fables of the 1st or 2nd century AD', in N Wilson (ed.), Encyclopedia of ancient Greece, pp. 119-120, Routledge, New York, NY.

Zafiropoulos, C.A., 2001, Ethics in Aesop's Fables: The Augustana collection, Brill, Leiden.

Zimmermann, R. 2014, 'Fable III. NT', in C.M. Furey, J.M. LeMon, B. Matz, T. Chr. Römer, J. Schröter, B. Dov Walfish et al. (eds.), Encyclopedia of the Bible and its Reception (EBR), pp. 650-651, vol. 8, De Gruyter, Berlin.

Zimmermann, R., 2015, Puzzling the Parables of Jesus. Methods and Interpretation, Augsburg Fortress, Minneapolis, MN.

Zimmermann, R., 2021, 'The Fables according to Babrius and the New Testament Parables. The Beginning of a Promising Dialogue', in A. Oegema, J. Pater \& M. Stoutjesdijk (eds.), Overcoming dichotomies: Parables, Fables, and similes in the Graeco-Roman World, WUNT, Mohr Siebeck, Tübingen, Forthcoming.

Zimmermann, R. \& Joubert, S. (eds.), 2017, Biblical ethis and application: Purview, validity, and relevance of biblical texts in ethical discourse, WUNT 384, Moh Siebeck, Tübingen. 